\title{
Student Interest in a Primary Care of Underserved Populations Course
}

Jennifer Edwards-Johnson, DO, MPH; Julie P. Phillips, MD, MPH; Andrea Wendling, MD

\begin{abstract}
BACKGROUND AND OBJECTIVES: Medical students often lack curricular offerings specific to the care of underserved populations. We surveyed first- and second-year students to inform the development of a 4-week course on the skills necessary to care and advocate for underserved populations within a primary care context. This study assessed students' interest in the potential course, interest in primary care (PC) and underserved care (UC), and factors that would make the course more or less interesting to students.
\end{abstract}

METHODS: The authors designed and offered a survey examining UC, PC, and course interest to all first- and second-year students at one institution. Open-ended free-text survey responses were qualitatively analyzed using content analysis.

RESULTS: Response rate was $72 \%$ (271/374). Most responding students (90\%; $198 / 220)$ were very to somewhat interested in UC; $60 \%(132 / 220)$ were very to somewhat interested in PC; and $79 \%(173 / 220)$ were very to somewhat interested in the described course. Very interested students were more likely to endorse interest in learning about community advocacy, having a faculty mentor, clinical care experience, and loan repayment than those with low course interest $(P<.001)$. Analysis of open-ended responses revealed an emphasis on advocacy and career feasibility, resulting in the inclusion of these topics in the final course curriculum.

CONCLUSIONS: This manuscript outlines potential areas of engagement for students demonstrating low or high interest in a Caring for Underserved Patients course. Our study may inform educators seeking to develop similar curricular interventions, particularly those who aim to recruit students to PC or UC careers.

(Fam Med. 2020;52(1):17-23.)

doi: 10.22454/FamMed.2020.486784

$\mathbf{W}$ idening US health disparities reflect a complex and evolving health care landscape that ineffectively addresses the roles of access to primary care, socioeconomic status, geographic location, and race and ethnicity on health. ${ }^{1,2}$ In particular, racial and ethnic minorities receive a range of health care services less often than

their urban counterparts ${ }^{3}$ Whi the Liaison Committee on Medical Education (LCME) recognizes the need for curricula that address care of underserved populations, pedagogy in this area is still new, varying in design and implementation, and ineffectively studied. ${ }^{4,5}$ Disparities curricula often neglect to address barriers to underserved careers that students have identified, such as lack of mentorship, concerns about career feasibility, and the ability to pay back loans. ${ }^{4,6-8}$ Moreover, these curricula are often longitudinal in nature, forcing students to identify and commit to a specific interest upon matriculation. ${ }^{9}$ Despite these limitations, early exposure of medical students to educational opportunities focused on underserved populations and early opportunities for networking have been shown to increase the diversity of the future health workforce. ${ }^{4,10}$

The College of Human Medicine at Michigan State University (MSUCHM) has an established record of commitment to training exemplary physicians dedicated to underserved populations and practicing primary care. ${ }^{11}$ Several successful programs have been developed for students interested in enhanced training and care of underserved populations, including the Leadership in Rural Medicine Programs, which emphasize primary- and community-based care for rural populations, ${ }^{9}$ and the Leadership in Medicine for the Underserved (LMU) program, which emphasizes care for underserved and vulnerable populations,
From the Sparrow-MSU Family Health Center, and the Department of Family Medicine (Drs Edwards-Johnson and Phillips), Michigan State University College of Human Medicine, East Lansing, MI (Dr Wendling). 
community engagement, and primary care. ${ }^{12}$ However, these programs are longitudinal, geared toward students with a significant and established interest in these populations, and primarily include curricula in the third and fourth years. At the time of this study, there were no elective programs at MSU-CHM designed to expose first- and second-year students to primary and underserved care careers, potentially fostering this interest. This paper describes the assessment of student interest in a potential course designed to introduce students to careers in underserved and primary care, as well as their preferences for the content of this course. Results may be used by other medical education programs that aim to develop similar experiences.

\section{Methods}

To assess potential interest in a course on underserved and primary care, we designed a cross-sectional, online, anonymous survey, that was offered to all MSU-CHM first- and second-year students in October of 2017. Meetings with key medical school stakeholders and rigorous literature review informed the content of the survey. Faculty with training and experience in qualitative and quantitative study design developed the survey instrument. Students were asked to complete a survey exploring future career plans and interest in potential curricular offerings. In the survey, the course was described as "an intersession (elective) about care of underserved populations in the United States (such as minority populations, rural populations, refugee care, prison health, etc)." Respondents were asked to state whether they would be more or less interested in the course if it included the following hypothetical course attributes: community advocacy experiences, clinical care experiences, faculty mentorship, or a research experience. We quantified student interest levels using a 4-point Likert scale that included very interested, moderately interested, somewhat interested, and not at all interested; after data collection, moderately and somewhat interested were collapsed to a single "somewhat interested" category. To determine student interest in $\mathrm{UC}, \mathrm{PC}$, and the potential Caring for Underserved Populations Intersession course, we included the following survey items, using a 4-point scale: "How interested would you be in an intersession on primary care of underserved populations?", "Are you interested in working with an underserved population?", and "Are you interested in primary care (family medicine, internal medicine, pediatrics, or med/peds with a primary care focus)?" Open-ended response format questions also asked students what topics they would like to see addressed or included in the hypothetical course. Finally, we collected demographic information, including race and ethnicity, geographical origin, family income, highest parental level of education, and self-reported disadvantaged background.

A link to the survey was sent to students via email, and they were given 4 weeks to complete the survey. No compensation was offered for completing the survey. Surveys were managed using Qualtrics software and the Michigan State University Institutional Review Board deemed the study exempt from review.

\section{Data Analysis}

We used descriptive statistics to characterize our data; nonresponses were excluded from analysis. Using ANOVA, mean scores between study groups of interest (URM students, disadvantaged students, and rural students) were compared. We also compared levels of interest in individual course attributes between students who were interested or not interested in the proposed intersession. Analyses were conducted using SPSS version 25.0 (SPSS for Macintosh, IBM Corp, Armonk, NY). The relationships between interest in underserved populations, interest in primary care, and interest in the described intersession were investigated using Pearson product-moment correlation coefficients. Hierarchical multiple regression analysis was used to further examine the relationships between demographic variables associated with the outcomes of interest. Significance for all analyses was set at $P<.05$.

Free-text results were analyzed using conventional content analysis. ${ }^{13}$ Qualitative results were analyzed by two authors, one with training and experience in qualitative data analysis, who instructed the other. The two authors reviewed the data repeatedly to gain a sense of the whole. These authors then iteratively reviewed the responses and collaboratively developed a detailed coding manual, based on the responses themselves, without use of a preexisting theoretical model (inductive category development). Each of these authors then independently coded the responses. Codes were grouped into themes in order to develop a conceptual model. The authors looked for heterogeneity within themes, searching for disconfirming evidence and including informative minority or single-student perspectives. Many student responses had multiple ideas and were thus coded in multiple categories. Discrepancies in coding were discussed until consensus was reached (code-recode strategy). Researchers engaged in a continuous process of reflexivity throughout the coding process.

\section{Results}

\section{Respondent Characteristics}

Of 374 medical students offered the survey, 271 (72 \%) responded. Firstyear students represented $51 \%$ of respondents (138) and 131 (49\%) were second-year students. URM students represented 18\% (44) of respondents. Among all students surveyed, $33 \%$ (88) self-identified as being from a disadvantaged background. Students from rural childhood residence represented $28 \%$ of respondents; suburban, $58 \%$ (156); and urban $14 \%$ (38). Demographics of the students who completed surveys were compared to the class as a whole using 
$\chi^{2}$ analyses. Results are shown in Table 1. Compared to their peers, survey respondents were more likely to be of rural origin and from families with incomes ranging from $\$ 50,000$ $\$ 99,999$ a year.

\section{Student Interest in Underserved Care}

The majority of students (90\%, $198 / 220)$ were very $(55 \%, 122 / 220)$ to somewhat $(35 \%, 76 / 220)$ interested in underserved care. This is consistent with previous research, which indicates that approximately $44 \%$ of MSU-CHM students will eventually practice in underserved communities. ${ }^{11}$ Consistent with previous literature, ${ }^{14,15}$ African-American students $(20 / 20,100 \%)$ were more likely than white students $(114 / 129,89 \%)$ to endorse an interest in underserved care $(P<.05)$. Differences were not statistically significant for other URM groups. Students from self-identified disadvantaged backgrounds were more likely to endorse an interest in underserved care $(61 / 64,95 \%$ vs $134 / 152,88 \% ; P<.05)$. Students from an urban childhood residence $(29 / 29,100 \%)$ were also more likely than both rural $(55 / 63,87 \%)$ and suburban students $(112 / 125,90 \%)$ to endorse interest in underserved populations $(P<.001)$.

Student Interest in Primary Care Many respondents $(60 \%, 132 / 220)$ were very $(29 \%, 64 / 220)$ to somewhat $(31 \%, 68 / 220)$ interested in primary care. While no differences were identified when students were compared by race, rural status, or class year, students from self-identified disadvantaged backgrounds (45/65, 69\% vs $88 / 152,58 \%$ ) were more likely to endorse an interest in primary care. Interest in caring for underserved populations correlated positively with student interest in primary care $(r=0.392 ; P<.001)$.

\section{Student Interest in Caring for Underserved Intersession}

Most respondents $(79 \%, 173 / 220)$ were very $(21 \%, 47 / 220)$ to somewhat $(57 \%, 126 / 220)$ interested in a potential course on primary care of underserved populations. Interest in the proposed intersession appeared to mirror student interest in underserved care. African-American students $(19 / 20,95 \%)$ were more likely than white students $(99 / 130,76 \%)$ to endorse an interest in the described intersession $(P<.05)$. Students from an urban childhood residence (28/29, 97\%) were also more likely than both rural $(49 / 63,78 \%)$ and suburban $(99 / 126,76 \%)$ students to endorse interest in the course. Both interest in underserved populations $(r=0.515)$ and interest in primary care $(r=.575)$ correlated highly with interest in the intersession $(P<.001)$. In hierarchical multiple regression analysis, after controlling for race, geographic origin did not predict interest in the intersession.

\section{Course Attributes: Quantitative \\ Findings}

Student interest in specific attributes of the potential course are summarized in Table 2 and Figure 1. Students who showed a high interest in the course description were more likely to be interested in community advocacy, having a faculty mentor, and a clinical care experience than those who expressed a low interest $(P<.05)$. Course interest also correlated highly with interest in learning about loan repayment ( $r=0.568$, $P<.001$ ). Among those who expressed high interest in the course, almost all were interested in having a faculty mentor (93\%) and a clinical care experience (95\%). In contrast, among

Table 1: Self-reported Demographic Characteristics of Survey Respondents and Comparisons to All MSU-CHM Students

\begin{tabular}{|c|c|c|c|}
\hline Category & Respondents* $(\mathrm{N}=\mathbf{2 7 1})$ & 2016-2017 Class Demographics $(\mathrm{N}=374)$ & $P$ Value \\
\hline Female & $58.9 \%(158)$ & $55.6 \%(208)$ & .496 \\
\hline Disadvantaged background & $33 \%(88)$ & $31 \%(115)$ & .642 \\
\hline \multicolumn{4}{|l|}{ Family Income } \\
\hline$\$ 0-\$ 49,999$ & $20.6 \%(36)$ & $20 \%(61)$ & \multirow{4}{*}{$<.001$} \\
\hline$\$ 50,000-\$ 99,9999$ & $40.0 \%(70)$ & $21.3 \%(65)$ & \\
\hline$\$ 100,000-\$ 249,999$ & $29.1 \%(51)$ & $44.5 \%(136)$ & \\
\hline$\$ 250,000$ or more & $10.3 \%(18)$ & $14.2 \%(43)$ & \\
\hline \multicolumn{4}{|l|}{ Race/Ethnicity } \\
\hline White & $61.9 \%(151)$ & $58 \%(217)$ & \multirow{5}{*}{.094} \\
\hline African American & $12.3 \%(30)$ & $10.4 \%(39)$ & \\
\hline Asian & $9.4 \%(23)$ & $6.7 \%(25)$ & \\
\hline Hispanic & $5.7 \%(14)$ & $9.1 \%(34)$ & \\
\hline Other & $10.7 \%(26)$ & $15.8 \%(59)$ & \\
\hline \multicolumn{4}{|l|}{ Size of Hometown } \\
\hline Rural & $27.9 \%(75)$ & $14.2 \%(53)$ & \multirow{2}{*}{$<.001$} \\
\hline Metropolitan (suburban or urban) & $72.1 \%(194)$ & $85.8 \%(321)$ & \\
\hline
\end{tabular}


Table 2: Comparisons of Attractiveness of Course Attributes Between Students With Low and High Interest in an Underserved Care Course

\begin{tabular}{|c|c|c|c|c|c|}
\hline \multirow[b]{2}{*}{ Course Attribute* } & \multicolumn{2}{|c|}{$\begin{array}{c}\text { Low Course Interest } \\
\text { ("Not at All Interested") N=47 }\end{array}$} & \multicolumn{2}{|c|}{$\begin{array}{c}\text { High Course Interest } \\
\text { ("Very Interested") } \mathrm{N}=44\end{array}$} & \multirow{2}{*}{$P$ Value } \\
\hline & Mean & $\begin{array}{l}\text { Standard } \\
\text { Deviation }\end{array}$ & Mean & $\begin{array}{l}\text { Standard } \\
\text { Deviation }\end{array}$ & \\
\hline Community advocacy & 0.23 & 0.60 & 0.72 & 0.58 & .001 \\
\hline Faculty mentor & 0.23 & 0.60 & 0.91 & 0.35 & .001 \\
\hline Research experience & 0.47 & 0.62 & 0.41 & 0.69 & .632 \\
\hline Clinical care experience & 0.11 & 0.67 & 0.93 & 0.33 & .001 \\
\hline
\end{tabular}

*Students were asked "Would having [course attribute] make you more or less interested in this intersession?" Each respondent's interest in each course attribute was scored using a scale from -1 to 1 (1: more interested, 0: no influence, -1: less interested). Mean and standard deviation are listed for each attribute, calculated based on the aggregate scores of all students who had low overall interest in the course and all students who had high overall interest in the course. Those students with moderate course interest were excluded from this analysis.

\section{Figure 1: Interest in Course Attributes Among All Survey Participants, by Level of Interest in the Primary Care of Underserved Patients Course}

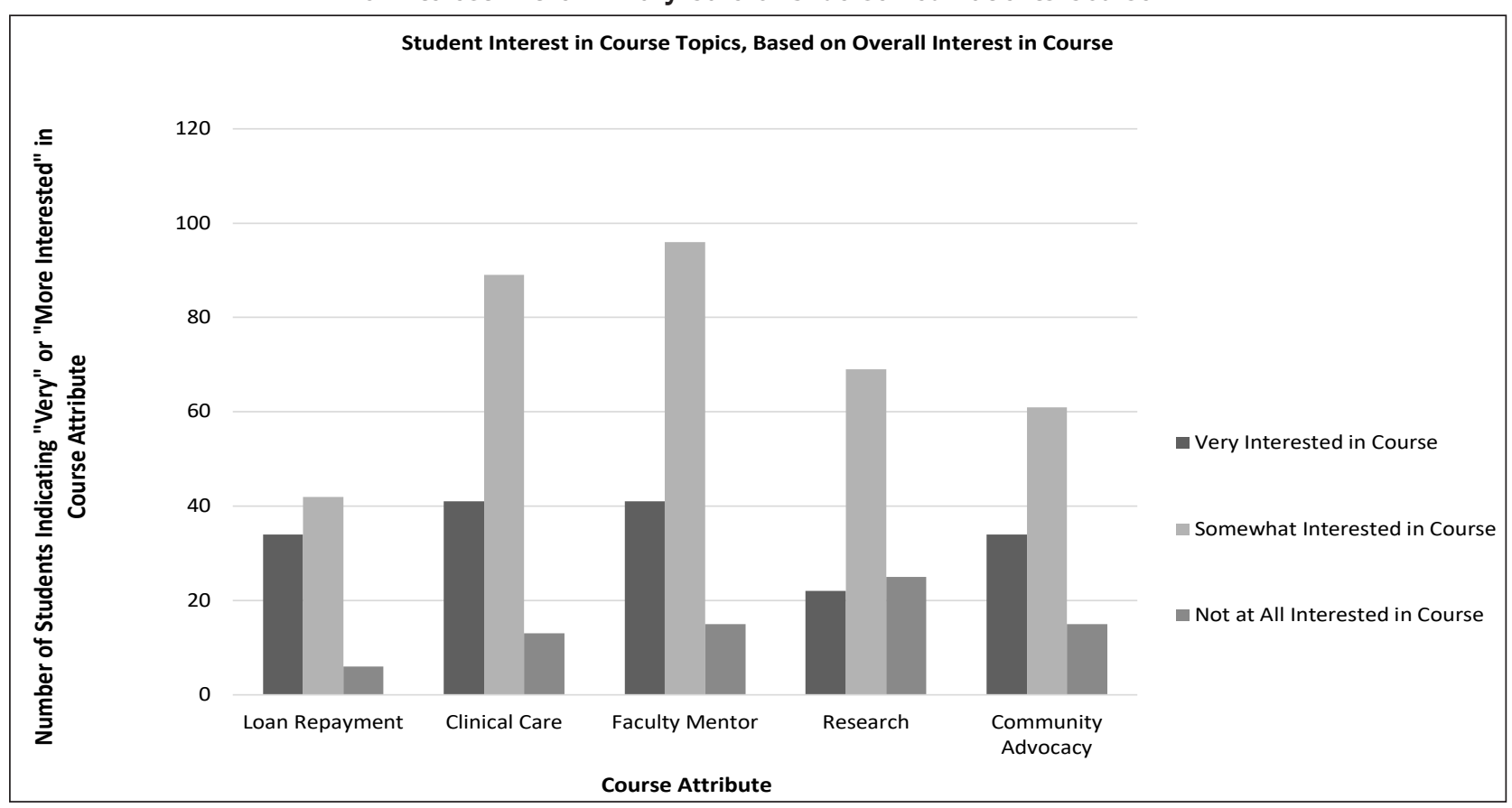

those who showed low interest in the intersession, the majority (53\%) were interested in a research experience, but had little interest in any other potential course attribute.

\section{Course Attributes: Qualitative Findings}

Content analysis of 218 student freetext responses identified nine major themes and several subthemes. Of the nine themes, two were particularly salient: "action" and "patient experience." Students expressed a desire for an action-oriented curriculum, in which they would learn about care of underserved patients through participation in the care itself. They expressed interest in participating directly in advocacy, community-engaged research, and patient care. Students also expressed interest in better understanding how underserved patients experience health care. Themes, subthemes, and example student responses are summarized in Table 3.
Notably, many students left the free-text response blank, indicated that they would not take the course, or responded with "nothing," or similar text. Thus, the responses primarily reflect the interests of students who would have a strong motivation to take the course. Of the few responses from students with low interest in the course, the most common themes were "common illnesses," "action," and "policy." These students appeared to be interested in an action-oriented curriculum, 
Table 3: Analysis of Student Responses to Open-Ended Question: "If You Were to Take an Intersession About Primary Care of Underserved Populations, What Topics Would You Like to See Addressed or Included?"

\begin{tabular}{|c|c|c|c|c|}
\hline Theme & Subthemes & $\begin{array}{l}\text { Number of } \\
\text { Responses }\end{array}$ & $\begin{array}{c}\text { Percent } \\
\text { of Total } \\
\text { Responses } \\
(n=218)\end{array}$ & Representative Quotes \\
\hline $\begin{array}{l}\text { 1. Geography: } \\
\text { Students were } \\
\text { interested in learning } \\
\text { about underserved } \\
\text { populations in different } \\
\text { specific underserved } \\
\text { locations. }\end{array}$ & $\begin{array}{l}\text { - Comparing urban, suburban } \\
\text { and rural populations } \\
\text { - Local populations: populations } \\
\text { immediately proximate to the } \\
\text { medical school/populations in } \\
\text { the state of Michigan } \\
\text { - Policy and its effects on people } \\
\text { by geographic location }\end{array}$ & 15 & 6.9 & $\begin{array}{l}\text { "I would like to learn about } \\
\text { the best way to approach } \\
\text { underserved medicine, } \\
\text { including underserved areas } \\
\text { in Michigan... and future } \\
\text { international opportunities for } \\
\text { us as physicians." } \\
\text { "differences in health problems } \\
\text { from urban and suburban } \\
\text { areas" }\end{array}$ \\
\hline $\begin{array}{l}\text { 2. Specific } \\
\text { populations: } \\
\text { Students expressed } \\
\text { interest in working } \\
\text { with specific } \\
\text { populations and } \\
\text { the skills needed to } \\
\text { accomplish this. }\end{array}$ & $\begin{array}{l}\text { - } \quad \text { LGBTQIA patients } \\
\text { - Immigrant, undocumented } \\
\text { person health, and refugee } \\
\text { health } \\
\text { - Women's health and gender } \\
\text { disparities } \\
\text { - Pediatric health } \\
\text { - Interpreter services } \\
\text { - Medical Spanish } \\
\text { - International health, hidden } \\
\text { populations, homelessness, } \\
\text { intersectionality, prison } \\
\text { health, indigenous } \\
\text { populations }\end{array}$ & 35 & 16.0 & $\begin{array}{l}\text { "LGBTQ care in underserved } \\
\text { areas, care of local refugees" } \\
\text { “...needs of the respective } \\
\text { underserved populations } \\
\text { here...perhaps participate in } \\
\text { quality improvement projects } \\
\text { at local FQHCs, conduct a } \\
\text { needs assessment of local } \\
\text { Native American or refugee } \\
\text { populations" }\end{array}$ \\
\hline $\begin{array}{l}\text { 3. Policy: } \\
\text { Students were } \\
\text { interested in } \\
\text { understanding and } \\
\text { addressing health care } \\
\text { system, government } \\
\text { and policy-based } \\
\text { problems. }\end{array}$ & $\begin{array}{l}\text { - Historical context of health } \\
\text { disparities (institutional } \\
\text { oppression) } \\
\text { - Public health outreach } \\
\text { - Fundamentals of US health } \\
\text { policy (eg, Medicare vs } \\
\text { Medicaid) } \\
\text { - Flint water crisis } \\
\text { - Public transportation } \\
\text { - Preventative care in resource- } \\
\text { poor communities } \\
\text { - Recent health policy legislation/ } \\
\text { changes }\end{array}$ & 44 & 20.2 & $\begin{array}{l}\text { "Public health and social } \\
\text { constructs that affect } \\
\text { underserved. Also learning } \\
\text { about how insurance works } \\
\text { would help cater care towards } \\
\text { underserved/uninsured" } \\
\text { "an overview of health policy, } \\
\text { ways to get involved in policy" }\end{array}$ \\
\hline $\begin{array}{l}\text { 4. Physician/ } \\
\text { provider } \\
\text { perspectives: } \\
\text { Students were } \\
\text { interested in } \\
\text { the perspectives } \\
\text { of providers on } \\
\text { underserved and } \\
\text { primary care careers. }\end{array}$ & $\begin{array}{l}\text { - Underserved care practice } \\
\text { models } \\
\text { - Career opportunities } \\
\text { - Physician financial well-being/ } \\
\text { loan repayment } \\
\text { - Physician work-life balance/call } \\
\text { - Role of specialists } \\
\text { - Role of those in non- } \\
\quad \text { underserved locations }\end{array}$ & 22 & 10.1 & $\begin{array}{l}\text { "How do [physicians] make their } \\
\text { practice model sustainable / } \\
\text { How do they balance work/life } \\
\text { obligations" }\end{array}$ \\
\hline
\end{tabular}


Table 3, continued

\begin{tabular}{|c|c|c|c|c|}
\hline Theme & Subthemes & $\begin{array}{l}\text { Number of } \\
\text { Responses }\end{array}$ & $\begin{array}{c}\text { Percent } \\
\text { of Total } \\
\text { Responses } \\
(n=218)\end{array}$ & Representative Quotes \\
\hline $\begin{array}{l}\text { 5. Patient } \\
\text { experience: } \\
\text { Students were } \\
\text { interested in how } \\
\text { underserved patients } \\
\text { experience health care. }\end{array}$ & $\begin{array}{l}\text { - Trust/mistrust in health care } \\
\text { - Race and racial bias } \\
\text { - How religion impacts patient } \\
\text { experience } \\
\text { - Unconscious bias } \\
\text { - Bias in health care access } \\
\text { - Patient reported barriers to } \\
\text { - } \text { access and health } \\
\text { - How providers can promote } \\
\text { patient empowerment } \\
\text { - How historical events shape } \\
\text { - } \text { patient experiences } \\
\text { - Cultural competency }\end{array}$ & 35 & 16.1 & $\begin{array}{l}\text { "How historical events have } \\
\text { influenced patient perspectives } \\
\text { of the institution of medicine } \\
\text { across many different groups" } \\
\text { "How to advocate for patients } \\
\text { that are illegal immigrants } \\
\text { or who are not United States } \\
\text { citizens (how to get them } \\
\text { adequate and affordable care } \\
\text { and resources)." }\end{array}$ \\
\hline $\begin{array}{l}\text { 6. Future: } \\
\text { Students were } \\
\text { interested in the future } \\
\text { of } \mathrm{PC} \text { and UC }\end{array}$ & $\begin{array}{l}\text { - Technology and underserved } \\
\text { care } \\
\text { - Future of primary care }\end{array}$ & 3 & 1.4 & $\begin{array}{l}\text { "The role technology plays } \\
\text { in reaching underserved } \\
\text { population. Benefits and } \\
\text { disadvantages" }\end{array}$ \\
\hline $\begin{array}{l}\text { 7. Action: } \\
\text { Students were } \\
\text { interested in } \\
\text { advocacy, community- } \\
\text { engaged research, } \\
\text { and specific actions } \\
\text { and skills needed to } \\
\text { care for underserved } \\
\text { populations. They } \\
\text { were also interested } \\
\text { in an action-oriented } \\
\text { curriculum. }\end{array}$ & $\begin{array}{l}\text { - } \text { Climate of hospitals serving } \\
\text { underserved populations } \\
\text { - } \quad \text { Community engagement } \\
\text { - } \quad \text { Community-based } \\
\text { participatory research } \\
\text { - } \quad \text { Underserved clinical } \\
\text { experiences } \\
\text { - Tangible practical skills/ } \\
\text { procedures } \\
\text { - } \text { Affordable resources } \\
\text { - Care management and } \\
\quad \text { coordination }\end{array}$ & 45 & 20.6 & $\begin{array}{l}\text { "Work environment of } \\
\text { hospitals serving underserved } \\
\text { populations-types of } \\
\text { physicians, dealing with possible } \\
\text { equipment shortages, difficulties } \\
\text { accessing specialty care, how do } \\
\text { we make it work." } \\
\text { "Practical skills-language, } \\
\text { clinical procedures, how to make } \\
\text { a financially viable practice" }\end{array}$ \\
\hline $\begin{array}{l}\text { 8. Patient education: } \\
\text { Students were } \\
\text { interested in education } \\
\text { and health literacy of } \\
\text { underserved patients. }\end{array}$ & $\begin{array}{l}\text { - Sexual health education } \\
\text { - Nutrition education }\end{array}$ & 6 & 2.8 & $\begin{array}{l}\text { "how to communicate disease } \\
\text { processes to populations with } \\
\text { little understanding of their } \\
\text { health" }\end{array}$ \\
\hline
\end{tabular}

the treatment of specific medical conditions, and opportunities to address health care system problems through government action.

\section{Discussion}

Addressing health disparities through curricular interventions requires creative solutions that balance galvanizing students with low interest in underserved care with retaining and encouraging those who are committed.

Our findings among highly interested students provide valuable insight. These students appear to be interested in opportunities to be "in the field" and receive mentorship about their potential career of interest. Students also had a high interest in understanding the perspectives of underserved patients. Sustaining the interest of students who are interested in primary and underserved care may mean providing them with tangible opportunities to explore this interest. Table 3 outlines, in detail, a wide breadth of topics that students were interested in exploring, which will be useful to others developing similar curricula.

Encouraging students with low interest in underserved and primary care may be more complicated. Students with low interest in an underserved primary care course appeared to be attracted to opportunities more likely to make them competitive students in the residency application process, such as research. This finding suggests that offering research opportunities as part of elective courses focused on underserved care may make these courses more attractive to students with low initial interest. As educators, we should continue to be diligent about helping students understand the potential ramifications of health disparities, and how they may affect future physicians, regardless of career path.

Students' expressed interest in hands-on, practical experiences, as well as their desire to better 
understand physician perspectives on underserved care, are consistent with previous literature that describes the benefits of mentorship and role modeling of underserved care. In particular, students from underrepresented backgrounds routinely cite a lack of mentorship opportunities as a barrier to entering primary and underserved care careers. ${ }^{4,-8}$ While literature regarding outcomes from brief heath disparities educational opportunities is sparse, one study showed an improvement in knowledge, attitudes, and confidence around health disparity information after an 8-week elective. ${ }^{16}$ Another medical school demonstrated an increase in minority student applications after a 1-week intensive curriculum. ${ }^{6,7}$ Providing students with brief, action-oriented opportunities to explore these careers, while networking with other students and faculty, may represent an opportunity for recruitment and retention of diverse students.

Our study has important limitations. The study explored the views of students at a single medical school in the United States; other institutions' student populations and formal health disparities education structure may be very different. Further, we collected data from a single cohort of first- and second-year medical students at a single point in time, using a nonvalidated survey. Because the researchers qualitatively analyzed free-text survey responses rather than interviews or focus groups, there was no opportunity to clarify or further explore statements made by each student. The researchers were able to overcome this limitation, to some extent, by analyzing a large number of freetext responses.
This study demonstrates that first- and second-year medical students are interested in opportunities to explore careers in underserved care, and describes specific course attributes that are attractive to these students. In the future, we plan to incorporate results of this assessment into the implementation of the 4-week elective, and evaluate course outcomes, including pre- and postcourse attitudes toward primary care and underserved care, as well as longitudinal practice outcomes.

FINANCIAL SUPPORT: The project described in this article was supported by grant number K02HP30816 from the Health Resources and Services Administration (HRSA), an operating division of the US Department of Health and Human Services. This article's contents are solely the responsibility of the authors and do not necessarily represent the official views of the Health Resources and Services Administration or the US Department of Health and Human Services.

CORRESPONDING AUTHOR: Address correspondence to Dr Jennifer Edwards-Johnson, 788 Service Road, B120 East Lansing, MI 48824. 517-420-3045. Fax: 517364-5764. jennifer.johnson2@hc.msu.edu.

\section{References}

1. Riley WJ. Health disparities: gaps in access, quality and affordability of medical care. Trans Am Clin Climatol Assoc. 2012;123:167-172.

2. Baciu A, Negussie Y, Geller A, Weinstein JN, eds. Communities in Action: Pathways to Health Equity. Washington, DC: National Academies Press; 2017.

3. Cooper-Patrick L, Gallo JJ, Gonzales JJ, et al. Race, gender, and partnership in the patientphysician relationship. JAMA. 1999;282(6):583589.

4. Smith SG, Nsiah-Kumi PA, Jones PR, Pamies RJ. Pipeline programs in the health professions, part 1: preserving diversity and reducing health disparities. J Natl Med Assoc. 2009;101:836-40, 45-51.

5. VanderWielen LM, Vanderbilt AA, Crossman SH, et al. Health disparities and underserved populations: a potential solution, medical school partnerships with free clinics to improve curriculum. Med Educ Online. 2015;20(1):27535
6. Vela MB, Kim KE, Tang H, Chin MH. Innovative health care disparities curriculum for incoming medical students. J Gen Intern Med. 2008;23(7):1028-1032

7. Vela MB, Kim KE, Tang H, Chin MH. Improving underrepresented minority medical student recruitment with health disparities curriculum. J Gen Intern Med. 2010;25(S2) (suppl 2):S82-S85.

8. Phillips JP, Wilbanks DM, Salinas DF, Doberneck DM. Educational Debt in the Context of Career Planning: A Qualitative Exploration of Medical Student Perceptions. Teach Learn Med. 2016;28(3):243-251.

9. Wendling AL, Phillips J, Short W, Fahey C, Mavis B. Thirty Years Training Rural Physicians: Outcomes From the Michigan State University College of Human Medicine Rural Physician Program. Acad Med. 2016;91(1):113-119.

10. Young ME, Thomas A, Varpio L, et al. Facilitating admissions of diverse students: A six-point, evidence-informed framework for pipeline and program development. Perspect Med Educ. 2017;6(2):82-90.

11. Phillips JP, Wendling AL, Fahey CA, Mavis $\mathrm{BE}$. The effect of a community-based medical school on the state and local physician workforce. Acad Med. 2018;93(2):306-313.

12. Wendling A, Mavis B, Rappley M. Preparing medical students to care for the underserved: Michigan State University's Leadership in Medicine for the Underserved Program. STFM Conference on Medical Student Education. Phoenix, AZ. 2016.

13. Hsieh HF, Shannon SE. Three approaches to qualitative content analysis. Qual Health Res. 2005;15(9):1277-1288.

14. Xierali IM, Nivet MA. The Racial and Ethnic Composition and Distribution of Primary Care Physicians. J Health Care Poor Underserved. 2018;29(1):556-570.

15. Xierali IM, Nivet MA, Fair MA. Analyzing physician workforce racial and ethnic composition associations: physician specialties (Part I). AAMC Analysis in Brief. 2014. https://www. aamc.org/download/401798/data/aug2014aibpart1.pdf Accessed September 24, 2018.

16. Gonzalez CM, Fox AD, Marantz PR. The evolution of an elective in health disparities and advocacy: description of instructional strategies and program evaluation. Acad Med. 2015;90(12):1636-1640. 